\title{
The Future of Paediatric Heart Interventions: Where Will We Be in 2030?
}

\author{
Tomohito Kogure ${ }^{1,2} \cdot$ Shakeel A. Qureshi ${ }^{1}$ (D)
}

Accepted: 1 September 2020 / Published online: 9 October 2020

(C) The Author(s) 2020

\begin{abstract}
Purpose of Review Cardiac catheterization therapies to treat or palliate infants, children and adults with congenital heart disease have developed rapidly worldwide in both technical innovation and device development in the previous three decades. By reviewing of current status of novel or development of devices and techniques, we will discuss what is likely to happen in paediatric heart intervention in the next decade.

Recent Findings Recently, biodegradable stents and devices, transcatheter pulmonary valve implantation for the native right ventricle outflow tract and MRI-guided interventions have been progressing rapidly with good immediate to early results. These are expected to be introduced and spread in the next decade although there are still challenges to overcome.

Summary The future of paediatric heart intervention is very promising with rapid development of technological progress.
\end{abstract}

Keywords Congenital heart disease $\cdot$ Cardiac catheterization $\cdot$ Biodegradable devices $\cdot$ Percutaneous pulmonary valve implantation · MRI-guided interventions

\section{Introduction}

Cardiac catheterization therapies for infants, children and adults with congenital heart disease (CHD) have progressed rapidly worldwide since Dr. William Rashkind reported the first balloon atrial septostomy for transposition of the great arteries in 1966 [1]. This was followed by the development of balloon valvoplasties and angioplasties in the 1980s [2, 3]. Stent implantation and coil embolization were developed in the 1990s [4, 5], and device closure of septal defect and patent ductus arteriosus became popular throughout the world in the 1990s and 2000s [6-9], as well as development of imaging technology $[10,11]$. Nowadays, hybrid interventions $[9,12]$

This article is part of the Topical Collection on Congenital Heart Disease

Shakeel A. Qureshi

shakeel.qureshi@gstt.nhs.uk

Tomohito Kogure

tomohito.kogure@gstt.nhs.uk

1 Department of Congenital Cardiology, Evelina London Children's Hospital, Guy's and St Thomas' NHS Foundation Trust,

London SE1 7EH, UK

2 Department of Cardiology, Tokyo Women's Medical University, Tokyo 162-0054, Japan and percutaneous pulmonary valve implantation are performed, supported by three-dimensional echocardiography or CT or MRI. Catheter intervention has become wellestablished, and the therapeutic range of interventions continues to expand with development of newer devices and techniques. In this article, we will describe the current status and future expectation of biodegradable stents and devices, transcatheter pulmonary valve implantation for the native right ventricle outflow tract and MRI-guided interventions as these are expected to become widespread in the next decade.

\section{Biodegradable Stents and Devices}

\section{Biodegradable Stents}

For congenital heart disease, biodegradable stents will likely have the most utility in small infants and children. Implantation of balloon-expandable metal stents is the primary technical tool to treat vascular stenosis. The major limiting factors using bare metallic stents for paediatric field are lack of growth as the child grows, and limited expansion potential, which might require complicated surgical reintervention, in addition to other common complications, such as stent thrombosis and late in-stent stenosis. The concept of biodegradable 
stent (BDS) has found traction as an alternative to bare metallic stents, both in adult and paediatric applications. BDS has a number of advantages over existing bare metallic stent designs. Once biodegraded, they potentially leave behind a healed endothelialized natural vessel with further growth potential. Furthermore, BDS can act as a platform similar to their metal counterparts for either drugs or genes to promote vessel growth. Finally, BDS is readily compatible with MRI and CT imaging.

Preclinical and clinical coronary studies showed late positive remodeling with normal vasomotor function after the stent disappears. BDSs have the potential to eliminate the need for repeated interventions. Long-term animal studies are warranted to confirm late positive remodeling and evaluate vessel growth and function following complete stent degradation and assess risks associated with stent fragment embolization during the degradation process.

Case reports using coronary artery bioresorbable stents in paediatric patients with small vessels off-label in Europe have emerged. Zartner et al. [13] have described the use of the Biotronik stent (Biotronik, Berlin, Germany), a magnesium stent, for stenting of a stenotic left pulmonary artery in a preterm infant. The same group also was the first to report the use of the stent for the treatment of an infant with recoarctation [14]. The bioresorbable vascular scaffold (BVS) system (Abbott Vascular, Santa Clara, CA, USA) had been commercially available, and some congenital centres attempted to use the BVS for infants with pulmonary arterial and venous disease [15]. Despite encouraging case reports for congenital heart disease, the Biotronik stent and BVS were discontinued by the companies because of disappointing long-term results for the treatment of coronary disease [16]. Currently, some of the different groups across the world have been working towards producing a BDS for paediatric patients with CHD [17]. The Illusicor stent (Tremedics Medical Devices LLC, TX, USA) and 480 Biomedical stent (480 Biomedical Inc., MA, USA) have been developed as a bioresorbable vascular scaffold (BRS) for CHD with preclinical experience [18-20]. Zinc bioresorbable stent (ZeBRa stent) (PediaStent LLC, OH, USA) is the newest BDS specifically designed for CHD. Table 1 depicts the current BRS for paediatric application still under development. In coronary interventions, the current study provides insights into the safety and performance of the MeRes100 stent (Meril Life Sciences Pvt. Ltd., Vapi, India), a novel second-generation sirolimus-eluting BRS, with up to 3-year follow-up [21]. Another secondgeneration BRS named Magmaris (Biotronik AG, Bülach, Switzerland), a newer generation magnesium-based BRS, has reported encouraging results based on a small number of non-RCT studies [22], and one case was reported as the first use of a Magmaris for native aortic coarctation in a small infant with success as a short-term bridge-to-surgery [23].

\section{Biodegradable Devices}

Transcatheter closure is the current standard of care for the treatment of atrial septal defects worldwide. The current devices utilize a metal framework to support the occlusive material and to permanently clamp the septum. The long-term presence of a significant amount of metal in the heart leads to rare but serious complications such as erosion, arrhythmias and thrombus formation, most likely related to incomplete endothelialization [24-28]. In addition, it makes crossing of the septum to access the left side of the heart difficult for future interventions, which significantly reduces future treatment options for these patients. Hence, biodegradable occluders have become a desirable alternative requirement. As early as 2003 , the first partially degradable occluder, BioSTAR (NMT Medical, Boston, MA, USA) with a metallic permanent framework (MP35N) and a bioresorbable membrane made from intestinal collagen, was introduced [29-33]. A tremendous step forward from non-degradable metal occluders to biodegradable occluders was made based on the successful development of BioSTAR and desirable clinical results, even though it was withdrawn from the market due to complications with wire fractures and inflammatory reactions locally related to the biologic material of the membrane [33]. Currently, several partially or fully biodegradable occlusion devices are being developed and evaluated [34-42] and have been at varying stages of animal experimental or clinical trial (Table 2). The Carag bioresorbable septal occluder (CARAG $\mathrm{AG}$, Baar, Switzerland) is the only device that is CE (Conformité Européene) marked.

\section{Carag Bioresorbable Septal Occluder}

The Carag bioresorbable septal occluder (CBSO) (CARAG AG, Baar, Switzerland) is a self-centering, double-disc device without any metal framework, composed of poly lactic-co-glycolic acid. Endothelialization of the device seems to be completed within 3 months, while the device usually starts to be resorbed after 6 months and completely resorbed within 2 years. CBSO has 3 size options: small for 4-12-mm defects, intermediate for 13$20 \mathrm{~mm}$, and large for $21-25-\mathrm{mm}$ defects. The animal trials were completed in 24 German Landrace pigs with created interatrial septal defects. All occlusion devices were observed to be correctly positioned without any residual shunt or dislocation after implantation, and there were no procedural or device-related complications. Complete endothelializations covered by thin and smooth whitish tissue layers were achieved in all specimens. No cellular inflammation reaction was observed [43•]. The CBSO was implanted in a first-in-man in 2014 in Germany and completed CE marking in 2017 as a result of preliminary data of successful outcome in all 14 patients, 8 with ASD and 6 with patent foramen ovale $[44,45]$. Several centres in Germany, Switzerland and other European countries will participate in the CBSO registry, post CE mark study, which is aiming to enroll up 
Table 1 Current biodegradable stents for paediatric application

\begin{tabular}{|c|c|c|c|c|c|c|c|}
\hline Stent & Company & Material & Design & Size variation & Profile & $\begin{array}{l}\text { Reabsorption } \\
\text { (months) }\end{array}$ & Approval stage \\
\hline Illusicor stent & $\begin{array}{l}\text { Tremedics Medical } \\
\text { Devices LLC }\end{array}$ & PLLA* & $\begin{array}{l}\text { Balloon } \\
\quad \text { expandable }\end{array}$ & $\begin{array}{l}\text { 3-8 mm diameter (ongoing } \\
\text { evaluation for } 10-20 \mathrm{~mm} \text { ) }\end{array}$ & $\begin{array}{l}5 \text { or } 6-\mathrm{Fr} \\
\text { delivery }\end{array}$ & 24 months & $\begin{array}{l}\text { Preclinical } \\
\quad(\text { ref } 18,19)\end{array}$ \\
\hline $\begin{array}{l}480 \\
\text { Biomedical } \\
\text { stent }\end{array}$ & $\begin{array}{l}480 \text { Biomedical } \\
\text { Inc. }\end{array}$ & $\mathrm{PLGA}^{\dagger} / \mathrm{PLCL}^{*}$ & Self-expanding & $7-10 \mathrm{~mm}$ diameter & $\begin{array}{l}5 \text { or 6-Fr } \\
\text { delivery }\end{array}$ & 12-18 months & $\begin{array}{l}\text { Preclinical } \\
\quad \text { (unpublished } \\
\text { data) }\end{array}$ \\
\hline ZeBRa stent & PediaStent LLC & Zinc alloy & $\begin{array}{l}\text { Balloon } \\
\quad \text { expandable }\end{array}$ & $6 \mathrm{~mm}$ diameter & N/A & N/A & $\begin{array}{l}\text { Preclinical } \\
\quad \text { (unpublished } \\
\text { data) }\end{array}$ \\
\hline
\end{tabular}

$* P L L A$ poly L-lactic acid, ${ }^{\dagger} P L G A$ poly lactic-co-glycolic acid, ${ }^{\dagger} P L C L$ poly lactide-co- $\varepsilon$-caprolactone

to 100 patients. Carag intends to perform a clinical trial in the USA under an investigational device exemption (IDE).

\section{Future Perspectives}

Biodegradable stents have additional challenges to overcome. Infants and children with CHD often need larger diameter stents to dilate obstructed blood vessels such as the aorta and pulmonary arteries. There are significant biomedical and engineering challenges related to durability from repeat collapse pressure and increasing elastic recoil with manufacture of larger diameter stents, especially when constructed from polymers. As ideal absorption time is unknown, there are ongoing concerns for morbidity related to thromboembolism of the BDS fragments to distal vasculature and local reactions to the degrading stents. However, there is a huge need for BDSs, which are desirable in children.

Biodegradable devices are a promising future. Some devices will be introduced into the market and may be able to replace metal devices. It makes it realistic to use the devices for small

Table 2 Partially or fully biodegradable occlusion devices

\begin{tabular}{|c|c|c|c|c|c|c|}
\hline Device & $\begin{array}{l}\text { Year of } \\
\text { introduction }\end{array}$ & Company or institute & Design & Biodegradability & Human study & $\begin{array}{l}\text { Ref. } \\
\text { no. }\end{array}$ \\
\hline $\begin{array}{l}\text { Immediate release } \\
\text { patch }\end{array}$ & 2002 & $\begin{array}{l}\text { Custom Medical } \\
\text { Devices, Greece }\end{array}$ & $\begin{array}{l}\text { Sleeve-shaped patch made of made from } \\
\text { biodegradable polyurethane foam }\end{array}$ & Fully & $\begin{array}{l}\text { Very small } \\
\text { multicentre } \\
\text { study }(n=13)\end{array}$ & 37 \\
\hline $\begin{array}{l}\text { Carag } \\
\text { bioresorbable } \\
\text { septal occluder }\end{array}$ & 2014 & $\begin{array}{l}\text { CARAG AG, } \\
\text { Switzerland }\end{array}$ & $\begin{array}{l}\text { Round double disc made of bioresorbable } \\
\text { PLGA* with two opposing foldable } \\
\text { polyester covers }\end{array}$ & Partially & $\begin{array}{l}\text { First-in-human } \\
\quad \text { study }(n=14)\end{array}$ & $\begin{array}{c}46 \\
4- \\
7\end{array}$ \\
\hline Double BioDisk & 2010 & $\begin{array}{l}\text { COOK Medical, } \\
\text { USA }\end{array}$ & $\begin{array}{l}\text { Porcine small intestinal submucosa covered } \\
\text { disc with two flexible nitinol rings }\end{array}$ & Partially & $\begin{array}{l}\text { Animal study } \\
\text { only }\end{array}$ & 38 \\
\hline $\begin{array}{l}\text { Double-umbrella } \\
\text { occluder }\end{array}$ & 2010 & $\begin{array}{l}\text { Nanyang } \\
\text { Technological } \\
\text { University, } \\
\text { Singapore }\end{array}$ & $\begin{array}{l}\text { Two self-expanding umbrellas disc made of } \\
\text { PLC** }\end{array}$ & Fully & $\begin{array}{l}\text { Animal study } \\
\text { only }\end{array}$ & 39 \\
\hline $\begin{array}{l}\text { Chinese Lantern } \\
\text { occluder }\end{array}$ & 2011 & $\begin{array}{l}\text { Nanyang } \\
\text { Technological } \\
\text { University, } \\
\text { Singapore }\end{array}$ & $\begin{array}{l}\text { Fully biodegradable polymers (PLC and } \\
\text { PCL***) featured with a unique pull-fold } \\
\text { mechanism }\end{array}$ & Fully & $\begin{array}{l}\text { Animal study } \\
\text { only }\end{array}$ & 40 \\
\hline $\begin{array}{l}\text { Fully biodegradable } \\
\text { ASD occluder }\end{array}$ & 2012 & $\begin{array}{l}\text { Second Military } \\
\text { Medical University, } \\
\text { China }\end{array}$ & $\begin{array}{l}\text { Double-disc device made of polydioxanone } \\
\text { which is similar design to Amplatzer septal } \\
\text { occluder }\end{array}$ & Fully & $\begin{array}{l}\text { Animal study } \\
\text { only }\end{array}$ & 41 \\
\hline $\begin{array}{l}\text { Totally } \\
\text { biodegradable } \\
\text { PLA-based } \\
\text { occluder }\end{array}$ & 2018 & $\begin{array}{l}\text { Shanghai Shape } \\
\text { Memory Alloy Co. } \\
\text { Ltd. China }\end{array}$ & $\begin{array}{l}\text { PLLA }^{\dagger} \text { skeleton and two discs made of } \\
\text { PDLLA fabrics }\end{array}$ & Fully & $\begin{array}{l}\text { Animal study } \\
\text { only }\end{array}$ & 42 \\
\hline $\begin{array}{l}\text { Fully degradable } \\
\text { PLLA occluders }\end{array}$ & 2016 & $\begin{array}{l}\text { Guangdong Academy } \\
\text { of Medical Sciences, } \\
\text { China }\end{array}$ & $\begin{array}{l}\text { Double-umbrella framework and two battle } \\
\text { fabrics both composed of PLLA }\end{array}$ & Fully & $\begin{array}{l}\text { Animal study } \\
\text { only }\end{array}$ & 43 \\
\hline
\end{tabular}

$* P L G A$ poly lactic-co-glycolic acid, $* * P L C$ poly lactide-co- $\varepsilon$-caprolactone, $* * * P C L$ poly $\varepsilon$-caprolactone, ${ }^{\dagger} P L L A$ poly L-lactic acid, ${ }^{\ddagger} P D L L A$ poly D Llactic acid 
Fig. 1 Deployment of the flared Venus P-valve. a Angiogram in the main pulmonary artery showing severe pulmonary regurgitation. b Positioning of the distal carrot of the Venus P-valve in the left pulmonary artery (LPA) using fusion imaging. $\mathbf{c}$ The deployment starting position in the proximal LPA. d, e After exposing the distal flare, the system is pulled free from the LPA origin before gradually deploying the rest of the valve frame. f Final angiogram after Venus P-valve implantation showing no pulmonary regurgitation

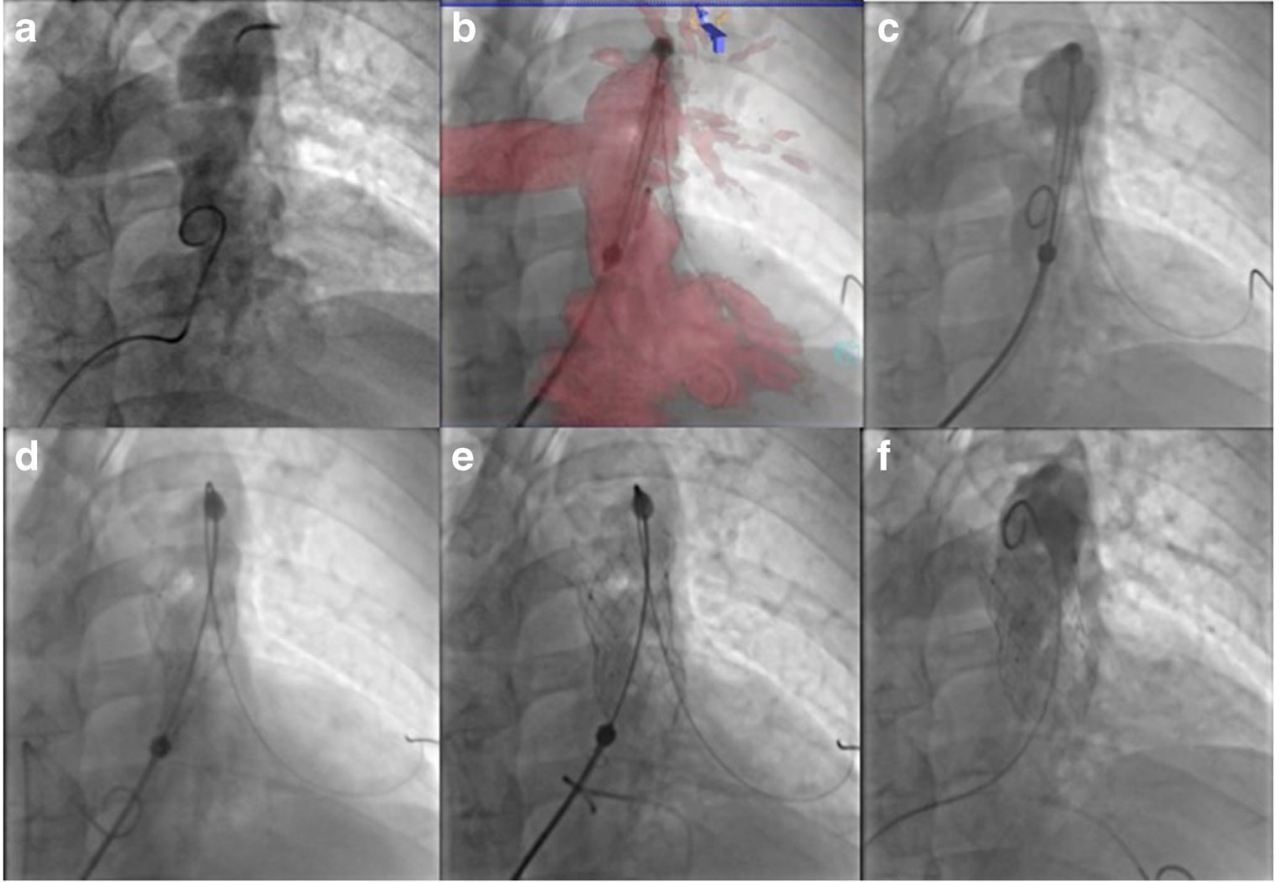

children and patients with severe metal allergies, who have been hesitant to be treated percutaneously. Furthermore, it is expected that similar techniques will be applied to other devices, such as patent ductus arteriosus occluder, ventricular septal defect occluder or other plug devices.

\section{Transcatheter Pulmonary Valve Implantation for the Native Right Ventricular Outflow Tract}

Pulmonary regurgitation after surgical repair of tetralogy of Fallot (ToF) is almost inevitable and, in the past, has required repeat surgery for replacing the regurgitant pulmonary valve. After 2000, percutaneous pulmonary valve implantation (PPVI) with balloon-expandable valves has replaced the surgical approach in a select group of patients. However, PPVI with the commercially available balloon-expandable valves have limitations because of their size, and being applicable to right ventricle-pulmonary artery conduits or bioprosthetic valves [46, 47]. They have been considered unsuitable for native dilated right ventricular outflow tracts (RVOTs) after a transannular patch repair technique, which form about 70$75 \%$ of the patients [48-52]. Novel self-expanding pulmonary valves, the Venus P-valve (Venus Medtech, Shanghai, China), the Pulsta valve (TaeWoong Medical Co., Ltd., Gimpo-si, Gyeonggi-do, South Korea) and the Harmony transcatheter pulmonary valve (Medtronic, Minneapolis, MN, USA), have been developed for this specific patient population.

All three valves are a porcine pericardial tissue valve mounted on a self-expanding nitinol frame and have proximal and distal flares that anchor the valve in the right ventricular outflow tract.
The Venus P-valve is one of the leading valves, which has an asymmetrical covering design, in which the pulmonary artery end flare is not covered, permitting unobstructed flow into the branch pulmonary arteries. Currently, the Venus P-valve is available in diameters from 16 to $36 \mathrm{~mm}$ with 2-mm increments, with each diameter available in 20-, 25-, 30- and 35-mm straight section lengths (Fig. 1). The valve can be implanted in the RVOTs, whose narrowest diameter is up to $33-34 \mathrm{~mm}$, for which a 36-mm-diameter valve can be implanted, which is the largest diameter valve currently available [53, 54••].

The Harmony transcatheter pulmonary valve is the only valve that will be available in the USA in the near future. The device has an outer diameter of $23.5 \mathrm{~mm}$ at the valved section and is approximately $55 \mathrm{~mm}$ in length. Lately, 3-year outcomes of Food and Drug Administration-approved early feasibility study have been reported by Benson et al. with a promising result of stable device position, good valve function in most, and the absence of moderate/severe paravalvular leak and significant late frame fractures [55]. Table 3 summarizes clinical studies of the commercially approved valves and the new self-expanding valves reported in the literature. Early experience with these valves, although limited, has been encouraging, suggesting that self-expandable pulmonary valves can be implanted safely in patients with native RVOTs, with good short- and mid-term results [55-62].

The Med-Zenith PT-Valve (Med Zenith, Beijing, China) is another self-expandable valve with good immediate result of first human study [63]. The Alterra Adaptive Prestent is another new concept of a self-expanding, partially covered stent, which was designed to internally reconfigure the native dilated RVOTs, such as to make them suitable for implantation of 


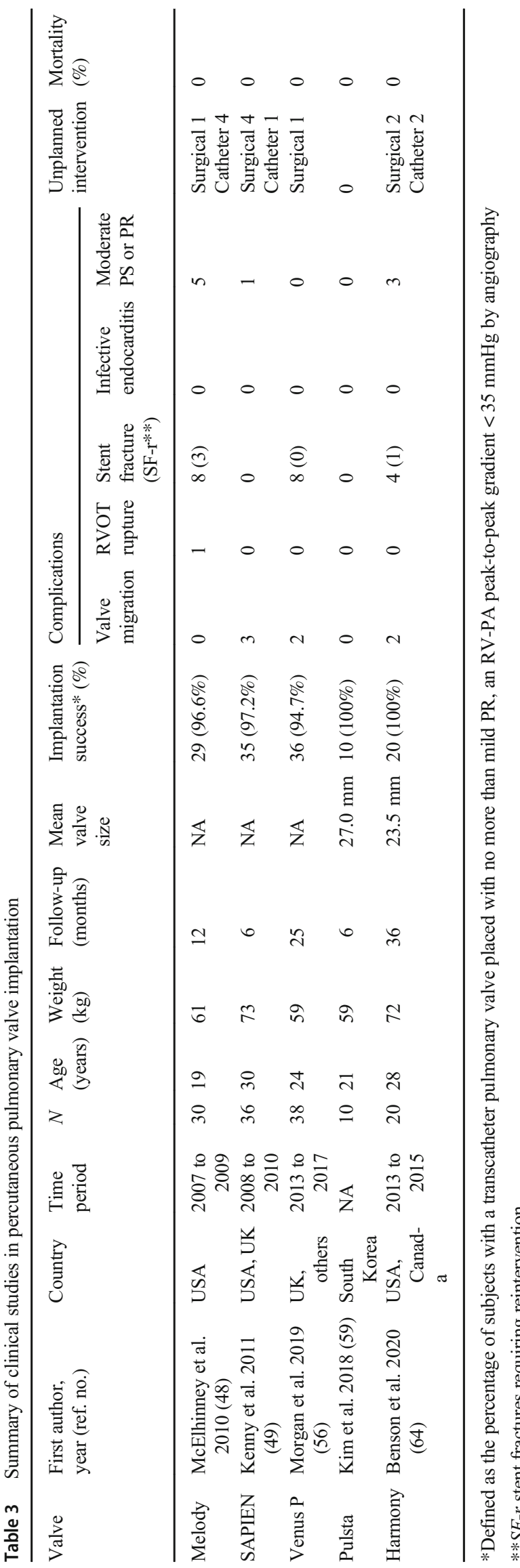

a commercially available balloon-expandable heart valve, the SAPIEN S3 transcatheter heart valve (Edwards Lifesciences, Irvine, CA, USA). The device has a symmetrical frame design to provide a rigid "landing zone" for a SAPIEN S3 (29 mm). Zahn et al. reported the first human implantation, which has shown encouraging results [64].

\section{Future Perspectives}

With further developments in the technology, a significant majority of patients may be potentially treatable by transcatheter valve technology within the next decade. The number of patients in whom transcatheter valve therapy may be an option has expanded with the advent of novel valves designed specifically for use in the larger, non-conduit, outflow tracts. Once this technology and valve-in-valve strategy are established, it will be possible to avoid repeat midline sternotomy and reduce the risk of repeat open surgery for the majority of ToF patients. In the not too distant future, if designing a percutaneous valve made of large scaffold with leaflets made of stem cell technology becomes a reality, it may be possible to avoid reoperations.

\section{MRI-Guided Interventions}

Diagnostic and interventional cardiac catheterization is routinely used in the diagnosis and treatment of CHD. However, the use of radiation during repetitive $\mathrm{x}$-ray-guided catheterization has led to concerns relating to the risk of solid tumours in later life, and that is particularly true in children, in whom increased radiation sensitivity, coupled with the possibility of repetitive exposure to diagnostic and interventional $\mathrm{x}$-ray procedures, can lead to a significant increase of cancer risk [65-70]. Magnetic resonance imaging (MRI) not only avoids exposure to radiation but also has the advantage of being able to provide better soft tissue visualization, tissue characterization and quantification of ventricular volumes and vascular flow [71, 72].

Initial work using MRI catheterization employed fusion of $\mathrm{x}$ ray and MRI techniques, with $\mathrm{x}$-ray fluoroscopy to guide catheter placement and subsequent MRI for anatomical and hemodynamic assessment. Image overlay of previously acquired 3D MRI datasets with live fluoroscopic imaging has also been used to guide catheter procedures [10]. More recent developments in passive and active catheter tracking have led to improved visualization of catheters for MRI-guided catheterization [73, 74]. Continuous development of equipment has also increased image quality and scanning times with better interactive tools for the operator in the MRI catheter suite to navigate through the anatomy as required in real time [75]. This has expanded to MRIguided electrophysiology (EP) studies and radiofrequency ablation in humans [76]. Animal studies show promise for the utility of MRI-guided interventional catheterization. With ongoing investment and development of MRI-compatible guidewires, 


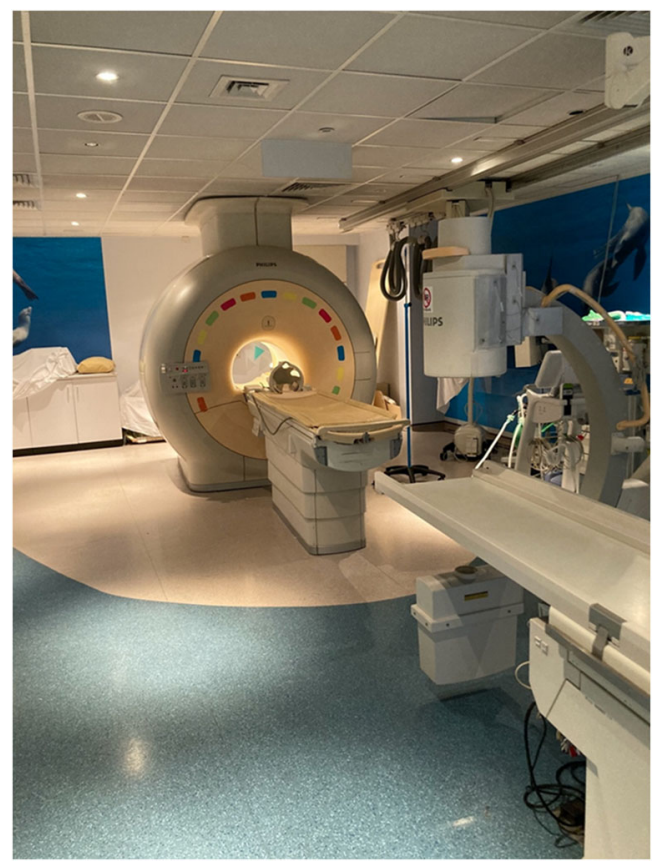

Fig. 2 X-ray and CMR (XMR) room. XMR room with the X-ray and MR equipment joined by a movable tabletop. The c-arm of the X-ray unit is seen in the right side and the 5-gauss area is demarcated by a change in the floor colouring from the MR to the x-ray end of the room

certain percutaneous cardiac interventions may be performed solely under MR guidance in the future [77, 78].

\section{Interventional Congenital Cardiac Procedures}

There have been a number of animal studies showing the safety and efficacy of interventional cardiovascular magnetic resonance (CMR) for congenital cardiac procedures. Animal interventional CMR has been used to facilitate procedures such as balloon angioplasty of arterial stenosis [79-81], atrial septal puncture/ septostomy [82] as well stenting of pulmonary arteries [83], aortic coarctation [84, 85] and vena cava intervention [86, 87]. Device closure of atrial septal defects is another application that has been explored [88-90]. Further animal studies also offer potential interventions in CHD such as transcatheter implantation of a prosthetic valve [91], percutaneous ventricular septal defect closure [92] and transcatheter creation of cavopulmonary shunts $[93,94 \cdot]$. Based on encouraging preclinical studies, the application of interventions has now been extended to humans. We reported the first-in-man solely MR-guided CHD interventions, balloon dilation of pulmonary valve, with promising results [95], and Krueger et al. reported balloon dilation of aortic coarctation under CMR guidance alone [81].

\section{Future Perspectives}

MR imaging-guided cardiac catheterization has become a clinical reality (Fig. 2), after years of technological development and preclinical/clinical testing $[11,71,96]$. There is a move for industry participation in the development of CMR-compatible cardiac catheters and devices specifically designed for CMR-guided cardiac intervention. Cardiac EP is the first field for which clinical grade device development is complete and in which human clinical trials are currently underway. Regarding congenital heart field, complex anatomy particularly requires wires and end-hole catheters with good steerability and torque to negotiate the bends of the relevant cardiac and vascular structures. Development needs to keep pace with the meticulous processes of regulatory approval of devices and also needs to be some verification in terms of the cost-effectiveness of these techniques and their role in improving patient outcomes. However, CMR-guided interventions in paediatric cardiology will continue to develop as a consequence of the continued striving for better anatomical and physiological data and avoidance of radiation. We predict that the next decade will see interventional MRI catheterization become a more widespread clinical reality.

\section{Conclusions}

Paediatric heart intervention has progressed from the initial balloon atrial septostomy performed in the 1960s. The future of interventions is very promising and exciting with the development of devices, techniques and imaging modalities. Bioresorbable stents and devices may be available commercially for use in CHD, and more patients will benefit from transcatheter pulmonary valve implantation. MRI-guided interventions in children will be introduced for wider clinical use in not too distant future. Technological progress is occurring at a tremendous pace. Innovative technology such as stem cell techniques and newer device development will be applied for treatment in paediatric cardiology.

\section{Compliance with Ethical Standards}

Conflict of Interest T. Kogure declares that they have no conflict of interest. Shakeel A Qureshi is a consultant for NuMED Inc.; Lifetech Inc., Occlutech, and Venus Medtech (PI for CE study).

Human and Animal Rights and Informed Consent All reported studies/ experiments with human or animal subjects performed by the authors have been previously published and complied with all applicable ethical standards (including the Helsinki declaration and its amendments, institutional/national research committee standards, and international/national/institutional guidelines).

Open Access This article is licensed under a Creative Commons Attribution 4.0 International License, which permits use, sharing, adaptation, distribution and reproduction in any medium or format, as long as you give appropriate credit to the original author(s) and the source, provide a link to the Creative Commons licence, and indicate if changes were made. The images or other third party material in this article are included 
in the article's Creative Commons licence, unless indicated otherwise in a credit line to the material. If material is not included in the article's Creative Commons licence and your intended use is not permitted by statutory regulation or exceeds the permitted use, you will need to obtain permission directly from the copyright holder. To view a copy of this licence, visit http://creativecommons.org/licenses/by/4.0/.

\section{References}

Papers of particular interest, published recently, have been highlighted as:

- Of importance

•- Of major importance

1. Rashkind WJ, Miller WW. Creation of an atrial septal defect without thoracotomy: a palliative approach to complete transposition of the great arteries. JAMA. 1966;196:991-2.

2. Kan JS, White RI Jr, Mitchell SE, Gardner TJ. Percutaneous balloon valvuloplasty: a new method for treating congenital pulmonary-valve stenosis. N Engl J Med. 1982;307:540-2.

3. Lababidi Z. Aortic balloon valvuloplasty. Am Heart J. 1983;106:751-2.

4. Hijazi ZM, Awad SM. Pediatric cardiac interventions. JACC Cardiovasc Interv. 2008;1:603-11.

5. Du ZD, Hijazi ZM, Kleinman CS, et al. Comparison between transcatheter and surgical closure of secundum atrial septal defect in children and adults: results of a multi-center non-randomized trial. J Amer Coll Cardiol. 2002;39:1836-44.

6. Holzer R, Balzer D, Cao QL, Lock K, Hijazi ZM, Amplatzer Muscular Ventricular Septal Defect Investigators. Device closure of muscular ventricular septal defects using the Amplatzer muscular ventricular septal defect occluder: immediate and mid-term results of a U.S. registry. J Amer Coll Cardiol. 2004;43:1257-63.

7. Masura J, Tittel P, Gavora P, et al. Long-term outcome of transcatheter patent ductus arteriosus closure using Amplatzer duct occluders. Am Heart J. 2006;151(755):e7-e10.

8. Carl HB, Brian KR, Jeffrey AB, et al. Percutaneous patent ductus arteriosus (PDA) closure during infancy: a meta-analysis. Pediatrics. 2017;139(2):e20162927. https://doi.org/10.1542/peds.2016-2927.

9. Holzer R, Marshall A, Kreutzer J, Hirsch R, Chisolm J, Hill S, et al. Hybrid procedures: adverse events and procedural characteristics-results of a multi-institutional registry. Congenit Heart Dis. 2010;5:233-42.

10. Abu Hazeem AA, Dori Y, Whitehead KK, Harris MA, Fogel MA, Gillespie MJ, et al. X-ray magnetic resonance fusion modality may reduce radiation exposure and contrast dose in diagnostic cardiac catheterization of congenital heart disease. Catheter Cardiovasc Interv. 2014;84:795-800.

11. Pushparajah K, Chubb H, Razavi R. MR-guided cardiac interventions. Top Magn Reson Imaging. 2018;27:115-28.

12. GalantowiczM, Cheatham JP, Phillips A, Cua CL, Hoffman TM, Hill SL, et al. Hybrid approach for hypoplastic left heart syndrome: intermediate results after the learning curve. Ann Thorac Surg. 2008;85:2063-70.

13. Serruys PW, Ormiston JA, Onuma Y, Regar E, Gonzalo N, GarciaGarcia HM, et al. A bioabsorbable everolimus-eluting coronary stent system (ABSORB): 2-year outcomes and results from multiple imaging methods. Lancet. 2009;373:897-910.

14. Zartner P, Cesnjevar R, Singer H, Weyand M. First successful implantation of a biodegradable metal stent into the left pulmonary artery of a preterm baby. Catheter Cardiovasc Interv. 2005;66(4):590-4.
15. Zartner P, Buettner M, Singer H, Sigler M. First biodegradable metal stent in a child with congenital heart disease: evaluation of macro and histopathology. Catheter Cardiovasc Interv. 2007;69(3):443-6.

16. Ali ZA, Serruys PW, Kimura T, Gao R, Ellis SG, Kereiakes DJ, et al. Two-year outcomes with the absorb bioresorbable scaffold for treatment of coronary artery disease: a systematic review and metaanalysis of seven randomized trials with an individual patient data substudy. Lancet. 2017;390:760-72.

17. Welch TR, Nugent AW, Veeram Reddy SR. Biodegradable stents for congenital heart disease. Intervent Cardiol Clin. 2019;8:81-94.

18. Herbert CE, Reddy SV, Welch TR, et al. Bench and initial preclinical results of a novel $8 \mathrm{~mm}$ diameter double opposed helical biodegradable stent. Catheter Cardiovasc Interv. 2016;88(6):902-11.

19. Nugent AW, Welch T. Development of large diameter bioresorbable stents for congenital heart disease. J Am Coll Cardiol. 2018;71(11 Supplement):A1353.

20. Ratnayaka. Purpose-built bioresorbable elastomer- polymer stent for aortic coarctation and pulmonary artery stenosis. Chicago: PICS-AICS Symposium; 2014.

21. Seth A, Onuma Y, Praveen Chandra P, et al. Three-year clinical and two-year multimodality imaging outcomes of a thin-strut sirolimus-eluting bioresorbable vascular scaffold: MeRes-1 trial. EuroIntervention. 2019;15:607-14. https://doi.org/10.4244/EIJ-D-19-00324.

22. Rapetto C, Leoncini M. Magmaris: a new generation metallic sirolimus-eluting fully bioresorbable scaffold: present status and future perspectives. J Thorac Dis. 2017;9(Suppl 9):S903-13. https://doi.org/10.21037/jtd.2017.06.34.

23. Sallmon H, Berger F, Cho MY, et al. First use and limitations of Magmaris ${ }^{\circledR}$ bioresorbable stenting in a low birth weight infant with native aortic coarctation. Catheter Cardiovasc Interv. 2019;93(7): 1340-3. https://doi.org/10.1002/ccd.28300.

24. Jux C, Wohlsein P, Bruegmann M, et al. A new biological matrix for septal occlusion. J Interv Cardiol. 2003;16:149-52.

25. Bissessor N. Current perspectives in percutaneous atrial septal defect closure devices. Med Dev Evid Res. 2015;8:297-303.

26. Mcelhinney DB, Quartermain M, Kenny D, et al. Relative risk factors for cardiac erosion following transcatheter closure of atrial sseptal defects: a case-control study. Circulation. 2016;133:1738-46.

27. Crawford GB, Brindis RG, Krucoff MW, Mansalis BP, Carroll JD. Percutaneous atrial septal occluder devices and cardiac erosion: a review of the literature. Catheter Cardio Inte. 2012;80:157-67.

28. Turner DR, Owada CY, SangJr CJ, et al. Closure of secundum atrial septal defects with the AMPLATZER septal occluder: a prospective, multicenter, post-approval study. Circ Cardiovasc Inte. 2017;10:004212.

29. Morgan G, Lee KJ, Chaturvedi R, et al. A biodegradable device (BioSTAR ${ }^{\mathrm{TM}}$ ) for atrial septal defect closure in children. Catheter Cardio Inte. 2010;76:241-5.

30. Mullen MJ, Devellian CA, Jux C. BioSTAR bioabsorbable septal repair implant. Expert Rev Med Devic. 2007;4:781-92.

31. Mullen MJ, Hildick-Smith D, Giovanni JVD, de Giovanni JV, Duke C, Hillis WS, et al. A prospective, multicenter, phase I clinical trial to evaluate the feasibility, efficacy, and safety of the BioSTAR bioabsorbable septal repair implant for the closure of atrial-level shunts. Circulation. 2006;114:1962-7.

32. Jux C, Bertram H, Wohlsein P, Bruegmann M, Paul T, Interventional atrial septal defect closure using a totally bioresorbable occluder matrix: development and preclinical evaluation of the BioSTAR device. J Am Coll Cardiol. 2006;48:161-9.

33. Happel CM, Laser KT, Sigler M, Kececioglu D, Sandica E, Haas NA. Single center experience: implantation failures, early, and late complications after implantation of a partially biodegradable ASD/PFO-device (BioStar $\left.{ }^{\circledR}\right)$. Catheter Cardiovasc Interv. 2015;85:990-7. 
34. Pavcnik D, Wright KC, Wallace S. Monodisk: device for percutaneous transcatheter closure of cardiac septal defects. Cardiovasc Inter Rad. 1993;16:308-12.

35. Zeinaloo A, Zanjani KS, Rastkar B, Hajizeinali A, Sohrabi B, Samadi M, et al. Closure of interatrial defects by immediaterelease patch. Pediatr Cardiol. 2012;33:1253-8.

36. Pavcnik D, Takulve K, Uchida BT, et al. Biodisk: a new device for closure of patent foramen ovale: a feasibility study in swine. Catheter Cardio Inte. 2010;75:861-7.

37. Duong-Hong D, Tang YD, Wu W, Venkatraman SS, Boey F, Lim $\mathrm{J}$, et al. Fully biodegradable septal defect occluder-a double umbrella design. Catheter Cardio Inte. 2010;76:711-8.

38. Wu W, Yip J, Tang YD, Khoo V, Kong JF, Duong-Hong D, et al. A novel biodegradable septal defect occluder: the "Chinese Lantern" design, proof of concept. Innovations. 2011;6:221-30.

39. Zhu Y, Huang X, Cao J, et al. Animal experimental study of the fully biodegradable atrial septal defect (ASD) occluder. J Biomed Biotechnol. 2012;2012:1-10.

40. $\mathrm{Lu} \mathrm{W}$, Ouyang W, Wang S, et al. A novel totally biodegradable device for effective atrial septal defect closure: a 2-year study in sheep. J Interv Cardiol. 2018;3:841-8.

41. Xie ZF, Wang SS, Zhang ZW, Zhuang J, Liu XD, Chen XM, et al. A novel-design poly-L-lactic acid biodegradable device for closure of atrial septal defect: long-term results in swine. Cardiology. 2016;135:179-87.

42. Shi D, Kang Y, Zhang G, Gao C, Lu W, Zou H, et al. Biodegradable atrial septal defect occluders: a current review. Acta Biomater. 2019;96:68-80.

43. Sigler M, Söderberg B, Schmitt B, et al. Carag bioresorbable septal occluder (CBSO): histopathology of experimental implants. EuroIntervention. 2018;13:1655-61 This is the first report on histopathology of a septal defect occluder with a bioresorbable filament structure in vivo. The Carag bioresorbable septal occluder is an impressive innovation which showed the future of bioresorbable devices.

44. Sievert H, Söderberg B, Mellmann A, et al. First human use and intermediate follow-up of a septal occluder with a bioresorbable framework. EuroPCR, 2015; Paris, Euro15A- OP336.

45. Soderberg B, Vaskelyte L, Sievert K, et al. Prospective single center first in human $(\mathrm{FIH})$ clinical trial to evaluate the safety and effectiveness of a septal occluder with bioresorbable framework in patients with clinically significant atrial septum defect (ASD) or patent foramen ovale (PFO). J Am Coll Cardiol. 2016;68(18 Suppliment B):334.

46. Kenny D, Hijazi ZM, Kar S, Rhodes J, Mullen M, Makkar R, et al. Percutaneous implantation of the Edwards SAPIEN transcatheter heart valve for conduit failure in the pulmonary position: early phase 1 results from an international multicenter clinical trial. $\mathrm{J}$ Am Coll Cardiol. 2011;58:2248-56.

47. McElhinney DB, Hellenbrand WE, Zahn EM, et al. Short- and medium-term outcomes after transcatheter pulmonary valve placement in the expanded multicenter US melody valve trial. Circulation. 2010;122:507-16.

48. Quail MA, Frigiola A, Giardini A, Muthurangu V, Hughes M, Lurz $P$, et al. Impact of pulmonary valve replacement in tetralogy of Fallot with pulmonary regurgitation: a comparison of intervention and nonintervention. Ann Thorac Surg. 2012;94:1619-26.

49. Babu-Narayan SV, Diller GP, Gheta RR, Bastin AJ, Karonis T, Li W, et al. Clinical outcomes of surgical pulmonary valve replacement after repair of tetralogy of Fallot and potential prognostic value of preoperative cardiopulmonary exercise testing. Circulation. 2014;129(1):18-27.

50. Bonhoeffer P, Boudjemline Y, Saliba Z, Merckx J, Aggoun Y, Bonnet $\mathrm{D}$, et al. Percutaneous replacement of pulmonary valve in a right-ventricle to pulmonary- artery prosthetic conduit with valve dysfunction. Lancet. 2000;356:1403-5.
51. Momenah TS, El-Oakley R, Al-Najashi K, et al. Extended application of percutaneous pulmonary valve implantation. J Am Coll Cardiol. 2009;53:1859-63.

52. Ansari MM, Cardoso R, Garcia D, Sandhu S, Horlick E, Brinster D, et al. Percutaneous pulmonary valve implantation, present status and evolving future. J Am Coll Cardiol. 2015;66:2246-55.

53. Promphan W, Prachasilchai P, Siripornpitak S, Qureshi SA, Layangool T. Percutaneous pulmonary valve implantation with the Venus P-valve: clinical experience and early results. Cardiol Young. 2016;26(4):698-710.

54.• Morgan G, Prachasilchai P, Promphan W, et al. Medium-term results of percutaneous pulmonary valve implantation using the Venus P-valve: international experience. EuroIntervention. 2019;14:1363-70 This article showed mid-term result of Venus P-valve implantation. The result has been encouraging, suggesting that self-expandable pulmonary valves can be implanted safely.

55. Benson LN, Gillespie MJ, Bergersen L, Cheatham SL, Hor KN, Horlick EM, et al. Three-year outcomes from the harmony native outflow tract early feasibility study. Circ Cardiovasc Interv. $2020 ; 13$ : e 008320 . https://doi.org/10.1161/ CIRCINTERVENTIONS.119.008320.

56. Cao QL, Kenny D, Zhou D, Pan W, Guan L, Ge J, et al. Early clinical experience with a novel self-expanding percutaneous stent-valve in the native right ventricular outflow tract. Catheter Cardiovasc Interv. 2014;84:1131-7.

57. Jones MI, Qureshi SA. Recent advances in transcatheter management of pulmonary regurgitation after surgical repair of tetralogy of Fallot. F1000 Res. 2018;7:679.

58. Zhou D, Pan W, Jilaihawi H, Zhang G, Feng Y, Pan X, et al. A selfexpanding percutaneous valve for patients with pulmonary regurgitation and an enlarged native right ventricular outflow tract: oneyear results. EuroIntervention. 2019;14:1371-7.

59. Kim GB, Kwon BS, Lim HG. First in human experience of a new self- expandable percutaneous pulmonary valve implantation using knitted nitinol- wire and tri-leaflet porcine pericardial valve in the native right ventricular outflow tract. Catheter Cardiovasc Interv. 2017;89(5):906-9.

60. Kim GB, Song MK, Bae EJ, et al. Successful feasibility human trial of a new self-expandable percutaneous pulmonary valve (Pulsta valve) implantation using knitted nitinol wire backbone and trileaflet $\alpha$-Gal-free porcine pericardial valve in the native right ventricular outflow tract. Circ Cardiovasc Interv. 2018;11:e06494.

61. Schoonbeek RC, Takebayashi S, Aoki C, et al. Implantation of the Medtronic Harmony transcatheter pulmonary valve improves right ventricular size and function in an ovine model of postoperative chronic pulmonary insufficiency. Circ Cardiovasc Interv. 2016;9(10).

62. Bergersen L, Benson LN, Gillespie MJ, Cheatham SL, Crean AM, Hor KN, et al. Acute and short-term outcomes with a selfexpanding transcatheter pulmonary valve. JACC Cardiovasc Interv. 2017;10(17):1763-73.

63. Shang X, Chen S, Zhang C, Wang B, Cheatham SL, Lu R, et al. First-in-man implantation of Med-Zenith PT-valve in right ventricular outflow tract for pulmonary regurgitation. JACC Cardiovasc Interv. 2019;12(19):1989-90.

64. Zahn EM, Chang JC, Armer D, Garg R. First human implant of the Alterra Adaptive Prestent ${ }^{\mathrm{TM}}$ : a new self-expanding device designed to remodel the right ventricular outflow tract. Catheter Cardiovasc Interv. 2018;91:1125-9.

65. Bashore TM, Bates ER, Berger PB, American College of Cardiology. Task Force on Clinical Expert Consensus Documents, et al. American College of Cardiology/Society for Cardiac Angiography and interventions clinical expert consensus document on cardiac catheterization laboratory standards. A report of the American College of Cardiology Task Force on 
clinical expert consensus documents. J Am Coll Cardiol. 2001;37:2170-214.

66. Chambers CE, Fetterly KA, Holzer R, et al. Radiation safety program for the cardiac catheterization laboratory. Catheter Cardiovasc Interv. 2011;77:546-56.

67. Venneri L, Rossi F, Botto N, Andreassi MG, Salcone N, Emad A, et al. Cancer risk from professional exposure in staff working in cardiac catheterization laboratory: insights from the National Research Council's biological effects of ionizing radiation VII report. Am Heart J. 2009;157:118-24.

68. Little MP, De Vathaire F, Charles MW, et al. Variations with time and age in the risks of solid cancer incidence after radiation exposure in childhood. Stat Med. 1998;17:1341-55.

69. Modan B, Keinan L, Blumstein T, Sadetzki S. Cancer following cardiac catheterization in childhood. Int J Epidemiol. 2000;29: $424-8$.

70. Johnson JN, Hornik CP, Li JS, Benjamin DK Jr, Yoshizumi TT, Reiman RE, et al. Cumulative radiation exposure and cancer risk estimation in children with heart disease. Circulation. 2014;130: 161-7.

71. Pushparajah K, Tzifa A, Razavi R. Cardiac MRI catheterization: a 10 -year single institution experience and review. Interventional Cardiol. 2014;6:335-46.

72. Rogers T, Ratnayaka K, Karmarkar P, Campbell-Washburn AE, Schenke WH, Mazal JR, et al. Real-time magnetic resonance imaging guidance improves the diagnostic yield of endomyocardial biopsy. JACC Basic Transl Sci. 2016;1:376-83.

73. Unal O, Li J, Cheng W, Yu H, Strother CM. MR-visible coatings for endovascular device visualization. J Magn Reson Imaging. 2006;23:763-9.

74. Mekle R, Hofmann E, Scheffler K, Bilecen D. A polymer-based MR-compatible guidewire: a study to explore new prospects for interventional peripheral magnetic resonance angiography (ipMRA). J Magn Reson Imaging. 2006;23:145-55.

75. Heathfield E, Hussain T, Qureshi S, Valverde I, Witter T, Douiri $\mathrm{A}$, et al. Cardiovascular magnetic resonance imaging in congenital heart disease as an alternative to diagnostic invasive cardiac catheterization: a single center experience. Congenit Heart Dis. 2013;8:322-7.

76. Weiss S, Wirtz D, David B, Krueger S, Lips O, Caulfield D, et al. In vivo evaluation and proof of radiofrequency safety of a novel diagnostic MR-electrophysiology catheter. Magn Reson Med. 2011;65:770-7.

77. Basar B, Rogers T, Ratnayaka K, Campbell-Washburn AE, Mazal JR, Schenke WH, et al. Segmented nitinol guidewires with stiffness-matched connectors for cardiovascular magnetic resonance catheterization: preserved mechanical performance and freedom from heating. J Cardiovasc Magn Reson. 2015;17:105.

78. Miquel ME, Hegde S, Muthurangu V, Corcoran BJ, Keevil SF, Hill DLG, et al. Visualization and tracking of an inflatable balloon catheter using SSFP in a flow phantom and in the heart and great vessels of patients. Magn Reson Med. 2004;51:988-95.

79. Godart F, Beregi JP, Nicol L, et al. MR-guided balloon angioplasty of stenosed aorta: in vivo evaluation using near-standard instruments and a passive tracking technique. J Magn Reson Imaging. 2000;12:639-44

80. Omary RA, Frayne R, Unal O, Warner T, Korosec FR, Mistretta $\mathrm{CA}$, et al. MR-guided angioplasty of renal artery stenosis in a pig model: a feasibility study. J Vasc Interv Radiol. 2000;11:373-81.

81. Krueger JJ, Ewert P, Yilmaz S, Gelernter D, Peters B̈, Pietzner $\mathrm{K}$, et al. Magnetic resonance imaging-guided balloon angioplasty of coarctation of the aorta: a pilot study. Circulation. 2006;113:1093-100.
82. Raval AN, Karmarkar PV, Guttman MA, Ozturk C, DeSilva R, Aviles RJ, et al. Real-time MRI guided atrial septal puncture and balloon septostomy in swine. Catheter Cardiovasc Interv. 2006;67:637-43.

83. Kuehne T, Saeed M, Higgins CB, Gleason K, Krombach GA, Weber OM, et al. Endovascular stents in pulmonary valve and artery in swine: feasibility study of MR imaging-guided deployment and postinterventional assessment. Radiology. 2003;226: 475-81.

84. Saeed M, Henk CB, Weber O, Martin A, Wilson M, Shunk K, et al. Delivery and assessment of endovascular stents to repair aortic coarctation using MR and X-ray imaging. J Magn Reson Imaging. 2006;24:371-8.

85. Raval AN, Telep JD, Guttman MA, Ozturk C, Jones M, Thompson $\mathrm{RB}$, et al. Real-time magnetic resonance imaging-guided stenting of aortic coarctation with commercially available catheter devices in swine. Circulation. 2005;112:699-706.

86. Arepally A, Karmarkar PV, Qian D, Barnett B, Atalar E. Evaluation of MR/fluoroscopy-guided portosystemic shunt creation in a swine model. J Vasc Interv Radiol. 2006;17:1165-73.

87. Shih MC, Rogers WJ, Hagspiel KD. Real-time magnetic resonance- guided placement of retrievable inferior vena cava filters: comparison with fluoroscopic guidance with use of in vitro and animal models. J Vasc Interv Radiol. 2006;17:327-33.

88. Rickers C, Jerosch-Herold M, Hu X, et al. Magnetic resonance image-guided transcatheter closure of atrial septal defects. Circulation. 2003;107:132-8.

89. Schalla S, Saeed M, Higgins CB, Martin A, Weber O, Moore P. Magnetic resonance-guided cardiac catheterization in a swine model of atrial septal defect. Circulation. 2003;108:1865-70.

90. Schalla S, Saeed M, Higgins CB, Weber O, Martin A, Moore P. Balloon sizing and transcatheter closure of acute atrial septal defects guided by magnetic resonance fluoroscopy: assessment and validation in a large animal model. J Magn Reson Imaging. 2005;21:204-11.

91. Kuehne T, Yilmaz S, Meinus C, Moore P, Saeed M, Weber O, et al. Magnetic resonance imaging-guided transcatheter implantation of a prosthetic valve in aortic valve position: feasibility study in swine. $\mathrm{J}$ Am Coll Cardiol. 2004;44:2247-9.

92. Ratnayaka K, Raman VK, Faranesh AZ, Sonmez M, Kim JH, Gutiérrez LF, et al. Antegrade percutaneous closure of membranous ventricular septal defect using X-ray fused with magnetic resonance imaging. JACC Cardiovasc Interv. 2009;2:224-30.

93. Ratnayaka K, Rogers T, Schenke W, Mazal JR, Chen MY, Sonmez $\mathrm{M}$, et al. Transcatheter bidirectional Glenn shunt guided by realtime MRI. J Cardiovasc Magn Reson. 2015;17:O23.

94. Ratnayaka K, Rogers T, Schenke W, et al. Magnetic resonance imaging-guided transcatheter cavopulmonary shunt. JACC Cardiovasc Interv. 2016;9(9):95970. https://doi.org/10.1016/j. jcin.2016.01.032 This document provides that real-time MRI enables percutaneous navigation of catheters outside vascular spaces to create an extra-anatomic connection between separate blood vessels, an approach that in the past has required open surgery.

95. Tzifa A, Krombach GA, Kramer N, et al. Magnetic resonanceguided cardiac interventions using magnetic resonancecompatible devices: a preclinical study and first-in-man congenital interventions. Circ Cardiovasc Interv. 2010;3:585-92.

96. Rogers T, Ratnayaka K, Lederman RJ. MRI catheterization in cardiopulmonary disease. Chest. 2014;145:30-6.

Publisher's Note Springer Nature remains neutral with regard to jurisdictional claims in published maps and institutional affiliations. 